\title{
Tracing the Spatial Patterns of Innovation Determinants in Regional Economic Performance
}

\author{
Alicja Olejnik \\ Department of Spatial Econometrics, Institute of Spatial Economy \\ Faculty of Economics and Sociology, University of Lodz, Poland \\ e-mail: alicja.olejnik@uni.lodz.pl
}

\author{
Agata Żółtaszek (iD \\ Department of Spatial Econometrics, Institute of Spatial Economy \\ Faculty of Economics and Sociology, University of Lodz, Poland \\ e-mail: agata.zoltaszek@uni.lodz.pl
}

\section{Abstract}

In this paper, we investigate innovation factors and their role in regional economic performance for a sample of 261 EU NUTS 2 regions over the period 2009-2012. In our study, we identify regions with spillover as well as drain effects of innovation factors on economic performance. The spatial analysis indicates that both regional innovativeness and regional development are strongly determined by the region's location and "neighbourhood", with severe consequences for Central and Eastern Europe. We assessed the impact of innovation factors and their spatial counterparts on economic performance using a spatial Durbin panel model. The model is designed to test the existence and strength of the country-effect of innovativeness on the level of regional economic status. This allows for controlling the country-specific socio-economic factors, without reducing the number of degrees of freedom. Our model shows that regions benefit economically from their locational spillovers in terms of social capital. However, the decomposition of R\&D expenditures revealed competition effect between internal $R \& D$ and external technology acquisition, favouring in-house over outsourced research.

Keywords: regional innovation, patterns of innovation, spatial spillover, common factors, spatial panel econometric model

JEL: O30, O33, C21, C23, R12 


\section{Introduction}

Recognising patterns of innovation is essential for designing and implementing policies that can help stimulate long-term output growth, improve productivity, as well as create jobs. Recognising innovation indicators is especially important at a regional level as it makes it possible to compare local innovation performance and its influence on the local economic development. Such evidence is undoubtedly vital for proper policymaking. However, the evolution of new technologies and ideas is not merely confined to regional administrative borders. A company in a given location can benefit from research conducted at a nearby university, as well as projects developed by companies located in nearby regions. By contrast, it would be more difficult for an individual firm to benefit from the innovative results of even the most dynamic region should it be geographically distant. Nevertheless, each year, the number of innovations carried out through collaborative networks is rising (c.f. Global Innovation Index 2016, as well as the 2017, 2018 and 2019 reports).

The Regional Innovation Scoreboard (RIS 2016; 2017; 2019) is an insightful analysis of innovation performance in European regions. RIS $2016^{1}$ is a study that considers the strengths and weaknesses of the regional innovation performance based on a number of indicators. These indicators include variables on Research and Development (R\&D) expenditure, patents, entrepreneurship, innovation collaboration, and the spread of innovative products.

Figure 1 presents RIS 2016 with four performance groups ranging from Innovation Leaders to Modest Innovators. We have 36 regions of Regional Innovation Leaders, 65 regional Strong Innovators, 83 regional Moderate Innovators, and 30 regional Modest Innovators. The Regional Innovation Leaders are located mainly in Sweden, Denmark, Finland, Germany, the Netherlands, the UK, and Île de France in France. Strong Innovators are regions located in Germany, Austria, Belgium, the Netherlands, the UK, France, Norway, Italy, País Vasco in Spain, and Bratislavský kraj in Slovakia. Countries with moderate innovating regions are situated mainly in the South (Portugal, Spain, Italy, Greece) as well as in the Central and Eastern EU states (Czech Republic, Slovakia, Hungary, Lithuania, Latvia, Estonia, Croatia, Poland, and Vzhodna Slovenijain in Slovenia), with additional locations, outliers in their own countries: Weser-Emsin Germany, Bassin Parisien, Nord-Pas-de-Calais, and Départements d'outre-mer in France. Finally, regional Modest Innovators are found in Romania, Bulgaria, Poland, some Greek, Italian, and Spanish islands, and Extremadura in Spain.

Overall, regions in Central and Eastern EU states and Sothern Europe have predominantly performed poorly in the assessment of innovativeness. Moreover, there are no Innovation Leaders and almost no Strong Innovators within the borders of these countries. This hinders any learning-from-the-best policies or spillover effects, and

1 Though the RIS 2017 and 2019 reports were published more recently, we refer to the 2016 study, as it is more appropriate for our data base. 
it slows the pace of the innovativeness and regional development in notable parts of Europe.

According to the RIS 2016 report, regional performance corresponds to the European Innovation Scoreboard (EIS 2016) country performance groups. As stated in the RIS report: "Almost all of the regional Innovation Leaders and Strong Innovators are located in the EIS Innovation Leader and Strong Innovator countries. Most of the regional Moderate and Modest Innovators are found in the EIS Moderate and Modest Innovator countries." Therefore, this might suggest the existence of a strong country-specific factor.

Tracing the patterns of innovation is a valid topic, which has been widely studied in the literature for years. However, it is noteworthy that the regional aspect had not been studied much until the seminal work of Jaffe (1989). In his work, a version of Griliches' (1979, pp. 92-116) Knowledge Production Function was applied at a regional level. Since publication, this paper has served as an example for various studies, such as Anselin et al. (1997, pp. 422-448), Crescenzi et al. (2007, pp. 673-709) Cabrer Borrás \& Serrano-Domingo (2007, pp. 1357-1371), and Gonçalves \& Almeida (2009, pp. 513-528). They all conclude that the proximity to highly innovative regions has a positive impact on their neighbours' development.

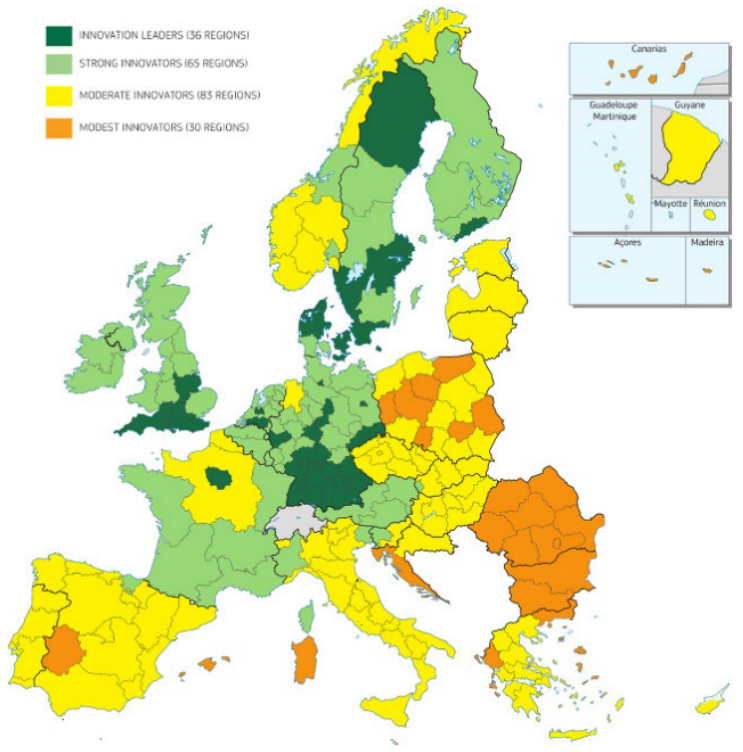

Figure 1. Regional Innovation Scoreboard 2016

Source: European Innovation Scoreboard 2016.

Intangible or knowledge-based capital has been widely recognised as an essential driver of innovation, growth, and competitiveness in advanced economies (c.f. Corrado et al. 2009, pp. 661-685; Corrado et al. 2017). There are several works which stress a significant correlation between social capital and economic growth. All social 
structures, and in particular, social networks, are essential factors for the economic outcome, on account of the decrease in information costs and the reduction of information asymmetries (Granovetter 2005, pp. 33-50). Caragliu and Nijkamp (2012, pp. 1363-1374) argue that insufficient levels of cognitive capital (that is social capital, which accounts for cognitive skills like norms, customs, and psychological dispositions towards socio-economic interactions) can hinder European regions from fully benefitting from newly produced knowledge.

In this paper, we aim to identify knowledge-based innovation factors that determine regional economic performance, and we will determine for which factors the complementary or competitive effect can be found. Moreover, as innovation is expected to occur in (regional) spatial patterns, we aim to test whether there are any common, national-specific factors. Implementing the country-specific effect (alternative to the standard regional fixed effects) constitutes an important value added to the regional studies. We developed and applied our own novel procedure to specify and estimate these country-specific effects in a spatial panel model.

In order to achieve this goal, first, we aim to identify regions and their clusters that share a similar level of innovativeness and their relation to regional development using spatial statistics. Then, as the central part of our analysis, we introduce a modified econometric spatial panel model to verify the innovation-based determinants of regional growth. Throughout the study, we focus on the regions of Central and Eastern Europe (CEE).

The rest of the paper is structured as follows. Section 2 describes the variables and data used in the empirical part of the analysis. Section 3 provides a brief theoretical background of uni- and bivariate Moran's I statistics as well as a presentation of the Durbin's Spatial Autoregressive Panel Model with spatial fixed effects used in the empirical part of the paper. The results of the analysis and the discussion are presented in Section 4. Section 5 offers a summary and some closing remarks.

\section{Determinants and data}

In our study, in line with the RIS report, we have selected innovative determinants of regional economic performance, namely high-tech employment and patent applications, which represent social capital and R\&D investments. The data used in the study are taken from the Eurostat Regional Database. Some missing data were interpolated from past trends and data derived from NUTS 1 and NUTS 0 levels. We considered $261 \mathrm{EU}$ regions from 27 countries from 2009 to 2012. For the description of the spatial structure for the EU regions, we used the three nearest neighbours (3nn) spatial weights matrix W (c.f. Anselien 1998).

To account for both the spatial and temporal aspects of our study, the dataset we employed requires not only contiguity of regions - to apply a spatial matrix - but also continuity in the time dimension. In turn, to obtain a balanced panel dataset for the 
maximal range of periods, due to the number of unavailable values at the time of the databank creation, we have decided to apply the earlier NUTS 2006 classification system (used between 2006 and 2011), with the converted values available for 2012. Further changes in the NUTS classification made it impossible to extend the panel. Consistent with RIS (2019), it is expected that the general spatial pattern found in the study would not change for an extended dataset.

While the data on tertiary education give valuable information on the prospective highly-qualified labour force in Europe, the indicator of employment in technology and knowledge-intensive sectors provides exact knowledge on the proportion of people actually working in technological and knowledge-intensive fields. Therefore, we used specifically this indicator as one of the critical factors of innovation. In our study, employment in technology and knowledge-intensive sectors $(\mathrm{H})$ refers to the share of employees in technology and knowledge-intensive sectors of the total number of the economically active population. Human capital in nearby locations is described by its spatial lag $(\mathrm{WH})$.

In our study, we use patent applications to the European Patent Office (EPO) as the other important element of social capital. However, we are aware that the intensity of patenting may vary depending on the sector or the characteristics of companies. Moreover, not all inventions are patented, patent values are different, and finally, not all patents lead to significant technological improvements. However, since all EU countries have national patent systems, and the data covers most technological fields, patents are often used as indicators of innovation. In this work, patents are represented by patent applications to the EPO by priority year per million of active population (EPO). Patent applications in neighbouring regions are defined by its spatial lag (WEPO).

Research and experimental development comprise creative work undertaken on a systematic basis in order to increase the stock of knowledge, including knowledge of man, culture and society, and the use of this stock of knowledge to devise new applications (Frascati, 2002). The intensity of research and experimental development (research and experimental development expenditures as a percentage of GDP) is an indicator of the high political importance at the EU, national and regional levels. Therefore, we use R\&D expenditures as one of the critical indicators of innovation. In our study, the variable R\&Dexp represents the total intramural R\&D expenditures, approximated by the gross domestic expenditure on R\&D (GRED) in purchasing power standard (PPS) (constant prices 2000) per economically active population. $R \& D$ expenditures in neighbouring regions are represented by its spatial lag (WR\&Dexp).

As a measure of regional performance, we take local gross domestic product per economically active population (expressed in thousands of people at the age of 15 and over), which has been converted into a common scale using purchasing power standard PPS (in millions), and expressed in constant prices from the year 2000. GDP in bordering regions is described by its spatial lag (WGDP). 
The distributions of variables used in the study in the last year of analysis - 2012 - are presented in Figure 2. All the variables are expressed in logarithms. Table 1 offers the descriptive statistics of the variables.

Table 1. Descriptive statistics of variables used in the analysis

\begin{tabular}{|c|c|c|c|c|c|}
\hline Variable & Description & Mean & $\sigma$ & Min & Max \\
\hline GDP & $\begin{array}{l}\text { Regional GDP in Millions (PPS, cs 2000) per } \\
\text { thousand of economically active population }\end{array}$ & 43.9 & 22.2 & 3.8 & 178.6 \\
\hline$R \& D \exp$ & $\begin{array}{l}\text { Total intramural R\&D expenditure (GERD) } \\
\text { (PPS, cs 2000) per economically active pop- } \\
\text { ulation }\end{array}$ & 764.3 & 782.7 & 11.3 & 6697.8 \\
\hline$H$ & $\begin{array}{l}\text { Employment in technology and knowledge-in- } \\
\text { tensive sectors per economically active pop- } \\
\text { ulation }\end{array}$ & 0.9 & 0.1 & 0.6 & 1.2 \\
\hline EPO & $\begin{array}{l}\text { Patent applications to the EPO by priority year } \\
\text { per million of economically active population }\end{array}$ & 199.0 & 231.2 & 0.0 & 1399.2 \\
\hline
\end{tabular}

Source: own study based on Eurostat data (https://ec.europa.eu/eurostat/web/regions/data/database) done in Matlab (accessed: 18.06.2019). 


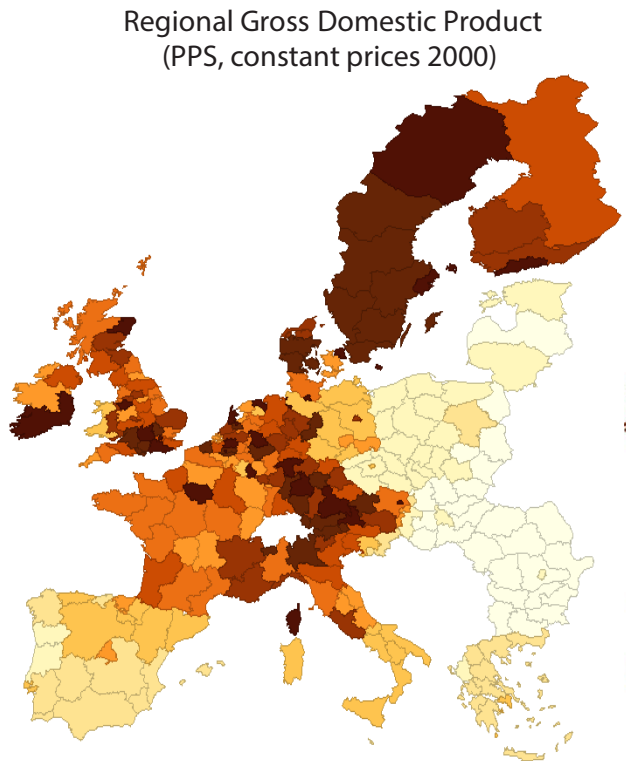

Employment in technology and knowledge-intensive sectors

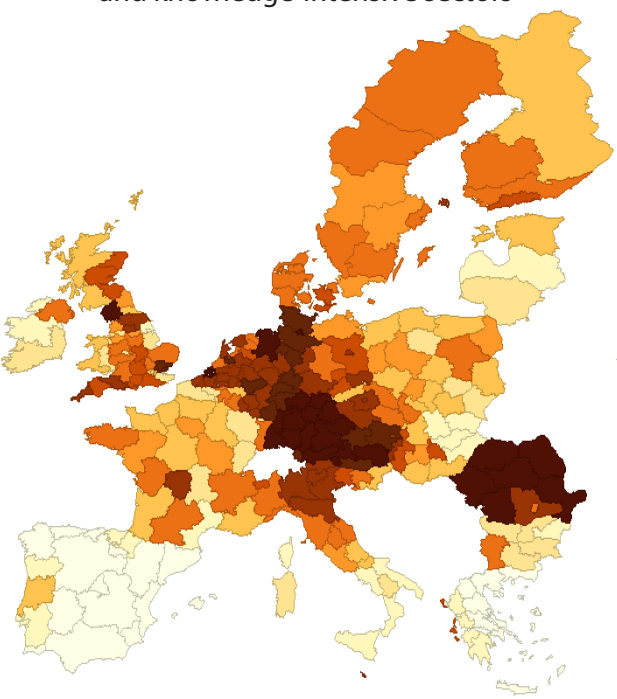

Total intramural R\&D expenditure

(PPS, constant prices 2000)

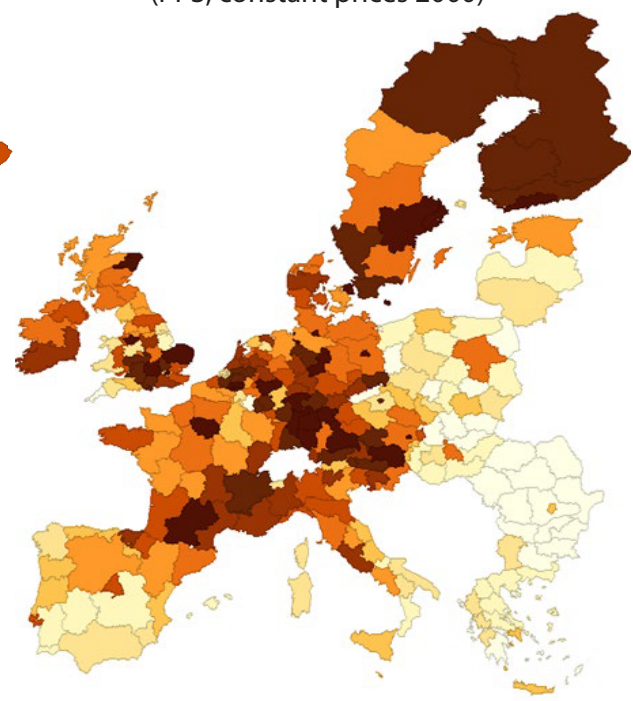

Patent applications to the EPO

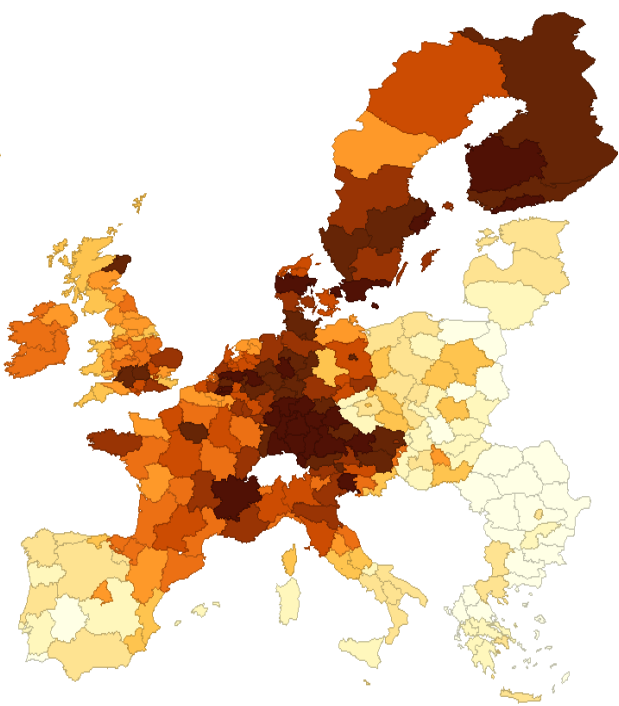

Figure 2. Variables used in the analysis, 2012

Source: own study based on Eurostat data (https://ec.europa.eu/eurostat/web/regions/data/database) done in GeoDa. (Shading of each variable is a quantile (10); the higher the value, the darker the colour) (accessed: 18.06.2019). 


\section{Theoretical background}

One of the most basic tools of spatial analysis is Moran's I statistic (Moran 1948, pp. 243-251; Cliff and Ord 1981). We distinguish two basic types of Moran's I statistics: local and global. As a measure of local spatial association, the local Moran's $I_{i}$ indicates if the $i$-th spatial object is surrounded by other spatial objects with similar (positive spatial autocorrelation) or significantly different (negative spatial autocorrelation) values of the variable in question

$$
I_{i}=\frac{\left(x_{i}-\bar{x}\right)}{\frac{1}{N} \sum_{i=1}^{N}\left(x_{i}-\bar{x}\right)^{2}} \sum_{j=1}^{N} w_{i j}\left(x_{j}-\bar{x}\right),
$$

where $x_{i}$ represents the variable in question, $\bar{x}$ its mean and $w_{i j}$ represents elements of spatial weight matrix W. On the other hand, the global Moran's I statistic is a more general measure of regional association as it expresses the likeness of all spatial objects as a mean of the local Moran's $I_{i}$ statistics

$$
I=\frac{\sum_{i=1}^{N} \sum_{j=1}^{N} w_{i j}\left(x_{i}-\bar{x}\right)\left(x_{j}-\bar{x}\right)}{\frac{1}{N} \sum_{i=1}^{N}\left(x_{i}-\bar{x}\right)^{2}}
$$

While both local and global Moran's I aim to measure the similarities and dissimilarities between one spatial variable, the bivariate local Moran's $I$ explains the spatial pattern formed by two different variables. That is, it measures spatial autocorrelation between variable $\mathrm{x}$ and another variable $(\mathrm{y})$ in nearby areas

with analogous notation.

$$
I_{i}=\frac{\left(x_{i}-\bar{x}\right)}{\frac{1}{N} \sum_{j=1}^{N}\left(x_{j}-\bar{x}\right)^{2}} \sum_{j=1}^{N} w_{i j}\left(y_{j}-\bar{y}\right),
$$

The generalisation of the cross-sectional spatial autoregressive (SAR) model (Ord 1975, pp. 120-127; Kelejian and Prucha 1998, pp. 99-121, and 2010, pp. 53-67) to the panel setting has been very popular in the literature. In addition to the spatial lag of the dependent variable, a spatial lag of independent variables can be included in the regression, which leads to the so-called spatial Durbin model (see, e.g., LeSage and Pace 2009). The identification of the spatial Durbin panel model concerns the effect of the spatial lags of the dependent variable in the presence of spatial time lags and exogenous spatial variables (Anselin et al. 2008, pp. 627-662; Elhorst 2014). This approach is a beneficial and flexible instrument in the process of specifying the econometric model, as it can incorporate the spatial lags of the exogenous variables on the right-hand side of the equation. In order to introduce some notation used in the study, we present a theoretical formula for the spatial Durbin panel model with spatial fixed effects 


$$
\mathbf{y}=\rho \mathbf{W} \mathbf{y}+\mathbf{X} \beta+\mathbf{W} \mathbf{X} \gamma+\vartheta, \vartheta=\left[\mu_{i}+\varepsilon_{i t}\right]_{i t}, \varepsilon_{i t} \sim N\left(0, \sigma^{2}\right),
$$

where $\mathrm{y}(\mathrm{NT} \times 1)$ is a vector of observations on the dependent variable and $\mathrm{X}(\mathrm{NT} \times \mathrm{K})$ represents a matrix of observations on $\mathrm{K}$ independent variables, $\mathrm{W}$ is a pre-defined spatial weight matrix representing the spatial structure of observations, WX is a matrix of spatial lags of the independent variables, $\mathbf{W y}$ spatially lagged vector dependent variable, $\rho$ is a spatial coefficient. Parameter $\varepsilon_{i t}$ is a vector of random errors, and $\mu_{i}$ represent spatial fixed effects, where $1 \leq i \leq \mathrm{N}$ and $1 \leq t \leq \mathrm{T}$.

In order to account for the role of country-specific effect, among others, we tested the spatial Durbin panel model with spatial group effects. In this newly developed spatial group effects model, instead of spatial fixed effects term $\mu_{i}$, we introduce the term $\varphi_{\text {group }(i)}, 1 \leq \operatorname{group}(i) \leq \mathrm{K}, 1 \leq i \leq \mathrm{N}$, where $\mathrm{K}$ represents the number of groups (Olejnik and Olejnik 2020).

$$
\mathbf{y}=\rho \mathbf{W} \mathbf{y}+\mathbf{X} \beta+\mathbf{W} \mathbf{X} \gamma+\vartheta, \vartheta=\left[\varphi_{\text {group }(i)}+\varepsilon_{i t}\right]_{i t}, \varepsilon_{i t} \sim N\left(0, \sigma^{2}\right),
$$

Notice that the spatial group fixed effects can be tested using a two-step procedure based on the augmented CD-test (c.f. Elhorst et al. 2018; Olejnik and Olejnik 2020).

\section{Results and discussion}

We start our analysis by focusing on individual regions and identifying clusters that share a similar level of innovativeness using univariate spatial statistics. This enables the identification of spillover effects for individual regions via hot and cold spots, as well as drain effects pinpointed by mixed clusters (hot-cold or cold-hot). In the second step, we confront the chosen innovation factors with the level of regional development by employing the bivariate Moran's measure to highlight individual regions for which high/ low levels of innovation factors in nearby locations coincide with high/low GDP.

Finally, we expand the spectrum of the analysis to search for more general mechanisms and regularities in the determinants of innovation factors. We aim to assess the statistical significance of each factor by incorporating a multivariable causality spatial Durbin panel model of economic performance determined by selected indicators of regional innovativeness and their spatial counterparts. Moreover, the model is designed to test the existence and strength of the country-effect of innovativeness on the level of regional economic status.

Below, local univariate and bivariate have been performed for 250 regions (as 11 regions have been defined as neighbour-less). Figures 3 and 4 report results from a univariate LISA analysis for the first (2009) and the final year of the study (2012). Figures 5 and 6 provide the results from bivariate LISA (2009 and 2012, respectively). 

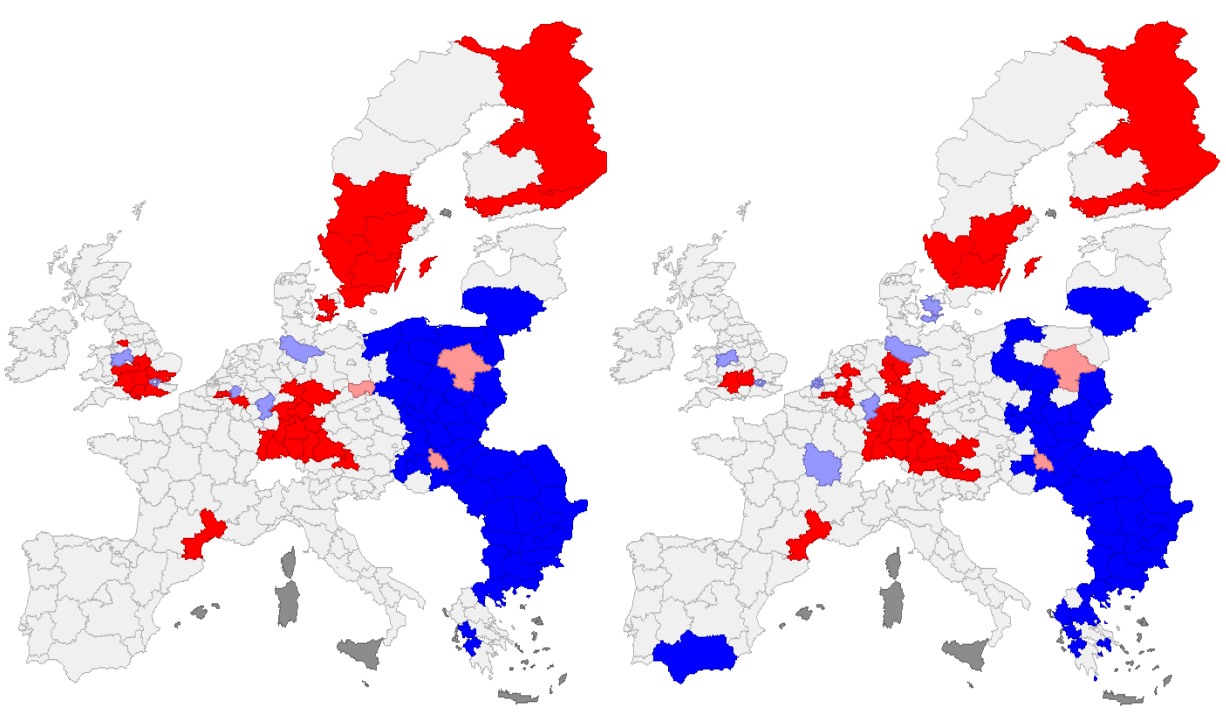

PO, 2009, Moran's I= 0.59
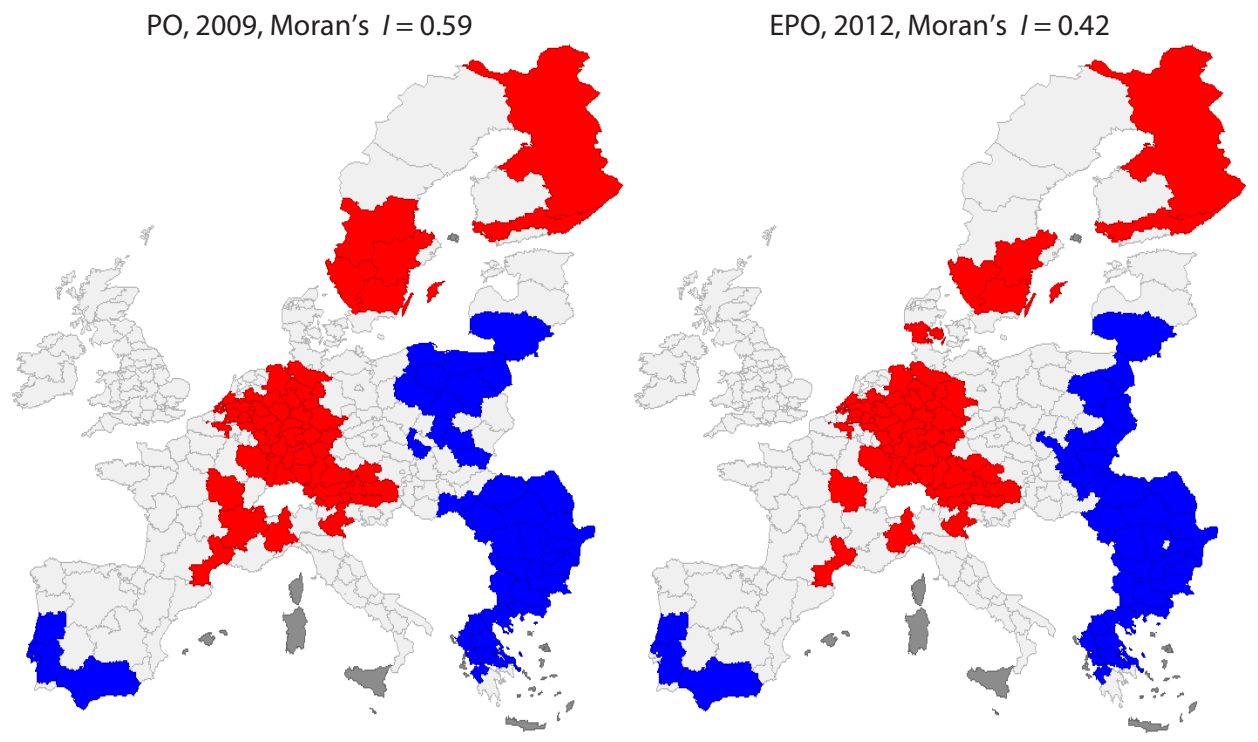

$\begin{array}{ll}\text { Colour legend for statistically significant outcomes } & \begin{array}{l}\text { Not Significant } \\ \text { High-High } \\ \text { Low-Low } \\ \text { Low-High } \\ \text { High-how } \\ \text { Neighoorless }\end{array} \\ \end{array}$

Figure 3. Univariate Local Moran's I for R\&D and EPO, 2009 and 2012

Source: own study based on Eurostat Regional Database done in GeoDa. 
Tracing the Spatial Patterns of Innovation Determinants in Regional Economic Performance

$\mathrm{H}, 2009$, Moran's $I=0.47$

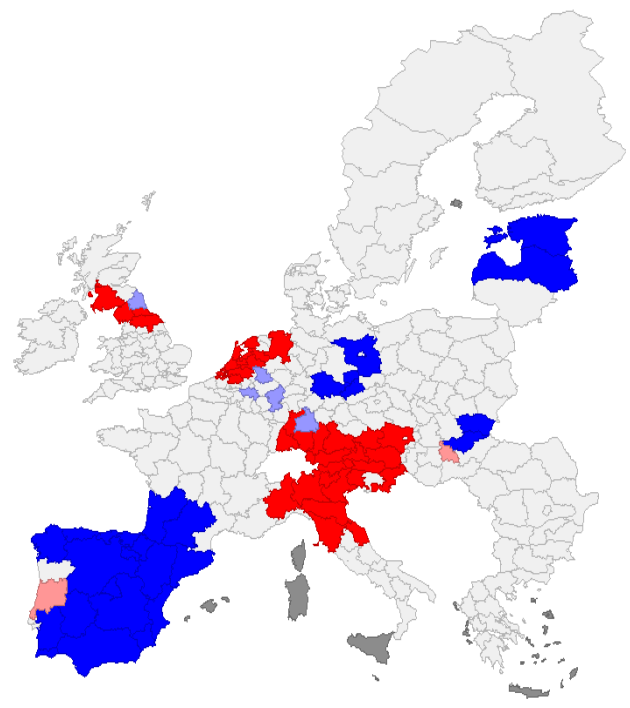

GDP, 2009, Moran's I 0.86

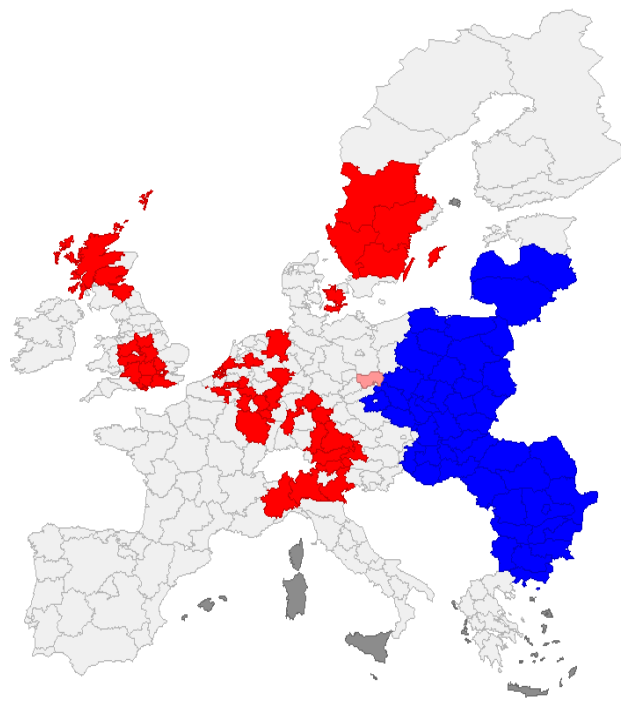

H, 2012, Moran's I = 0.66

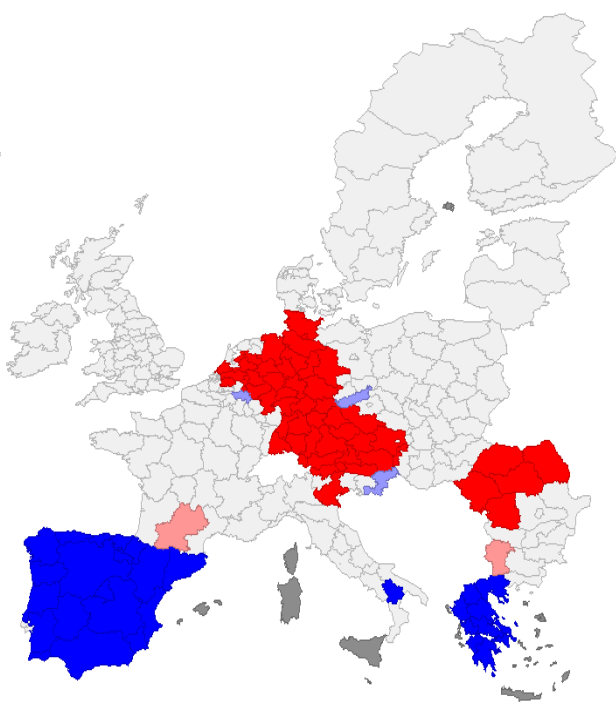

GDP, 2012, Moran's I $=0.85$

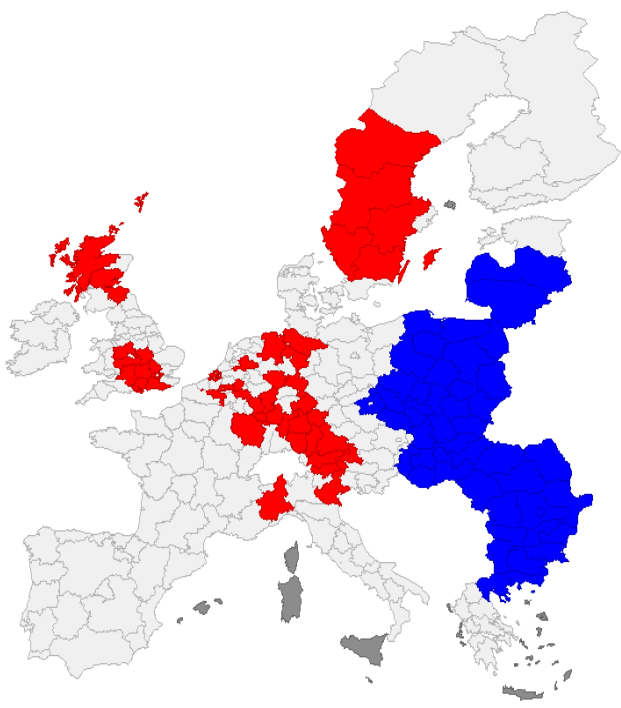

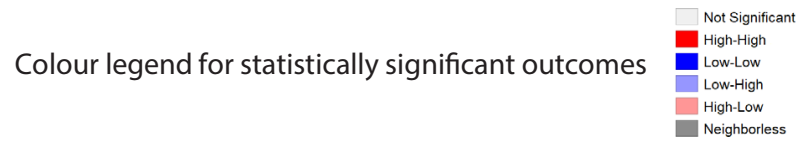

Figure 4. Univariate Local Moran's I for H and GDP, 2009 and 2012

Source: own study based on Eurostat Regional Database done in GeoDa. 

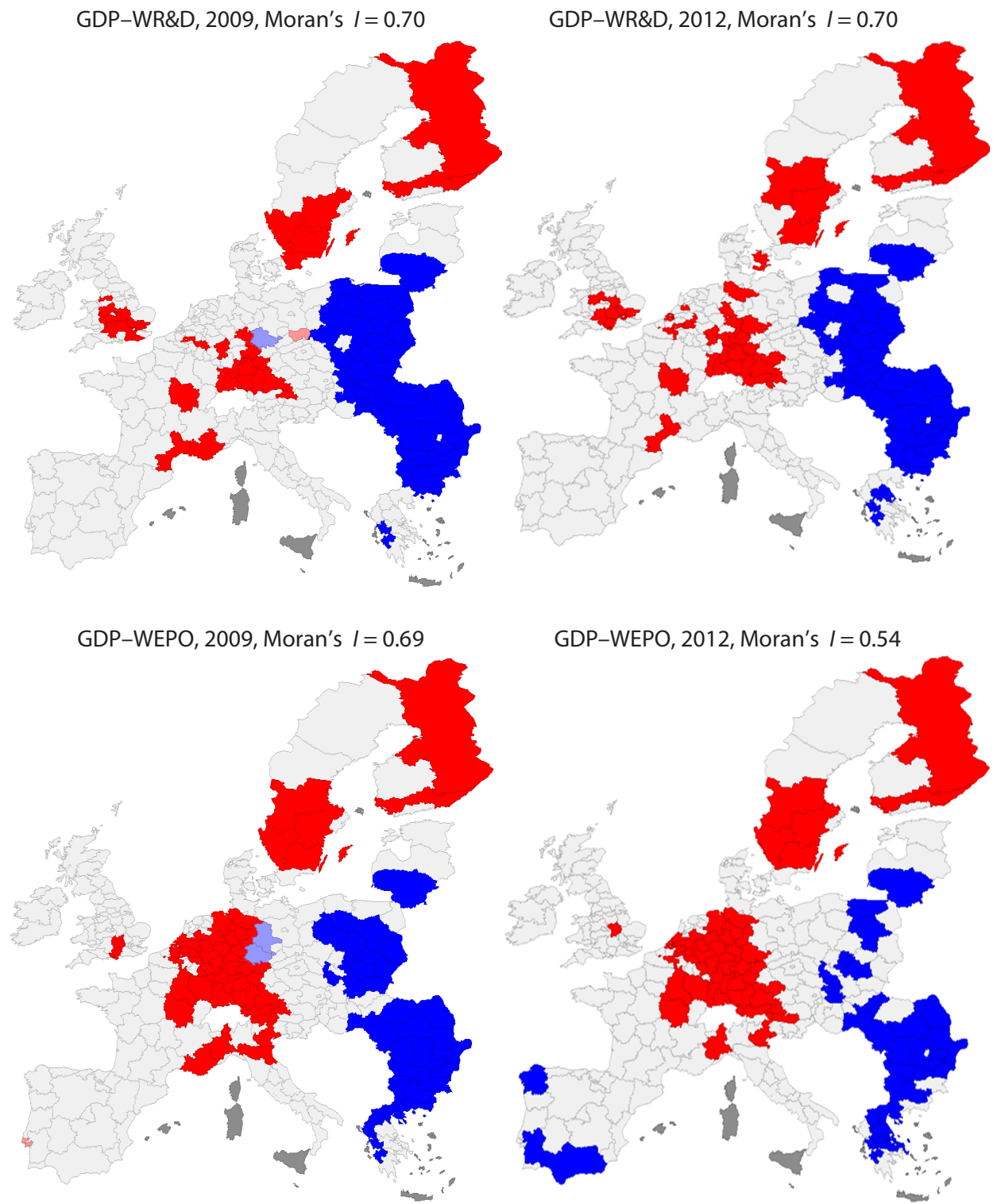

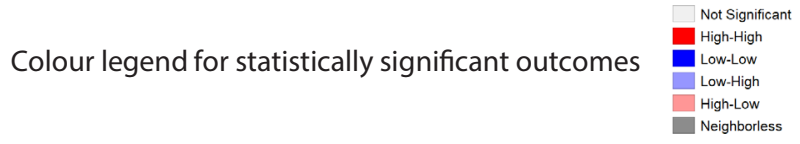

Figure 5. Bivariate Local Moran's I, for GDP with WR\&D and WEPO

Source: own study based on Eurostat Regional Database done in GeoDa. 


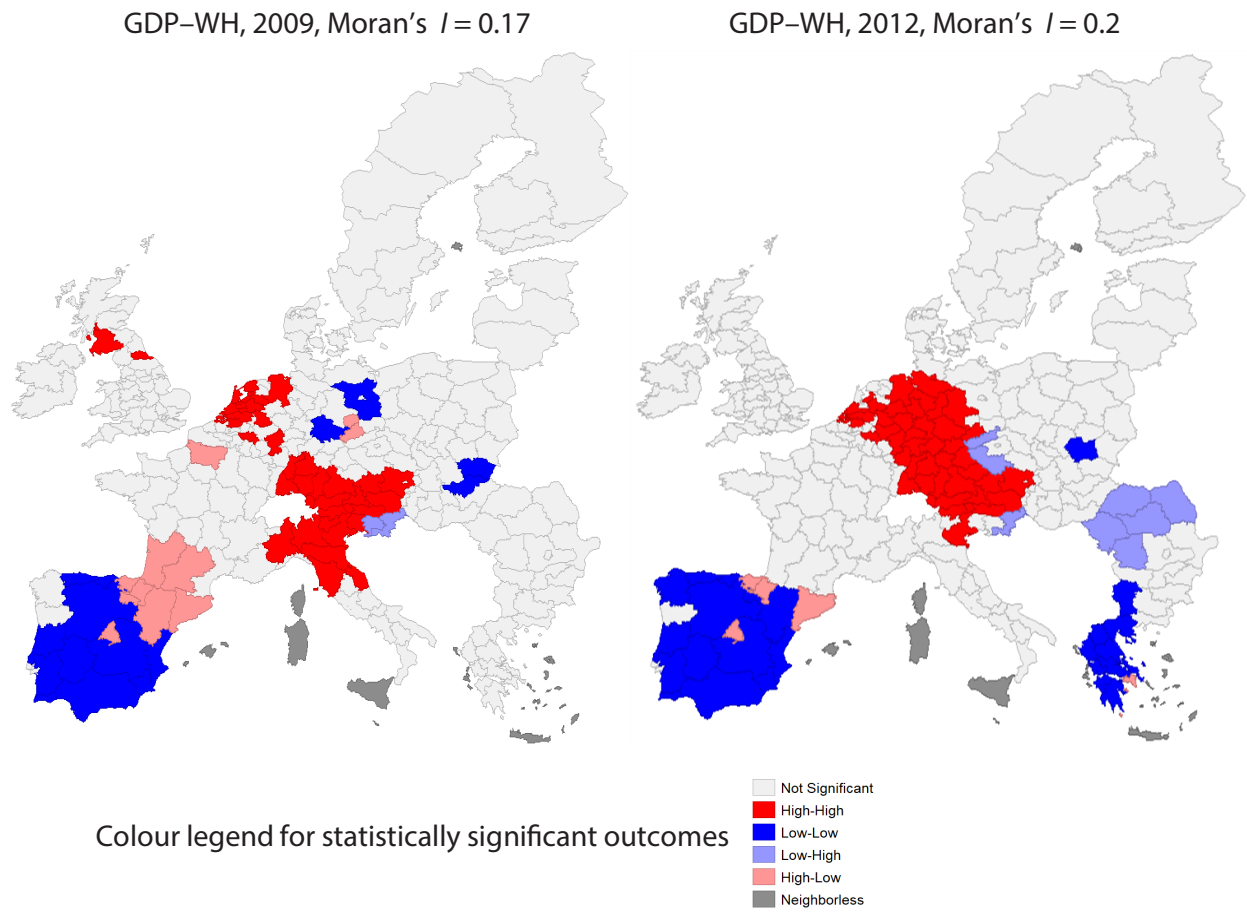

Figure 6. Bivariate Local Moran's I, for GDP with WH

Source: own study based on Eurostat Regional Database done in GeoDa.

The spatial autocorrelation for the total intramural $\mathrm{R} \& \mathrm{D}$ expenditures is high, with Moran's $I=0.6$. From the maps, we can observe 33 clusters of regions with high R\&D expenses surrounded by regions also with high expenditures (high-high, hot-spots) in Finland, Southern Sweden, Germany, a few regions in the UK, Alsace and Tarn in France, Liège in Belgium, Luxembourg, Sjælland in Denmark, and Salzburg in Austria. Due to low values of R\&D expenditures in the whole CEE region (see Figure 2), we have 41 low-low clusters (cold-spots or regions with low R\&D expenses bordering areas with similarly low expenditures) located mainly in the Eastern part of the EU. The spatial pattern seems to be similar for 2009 and 2012, except for Andalusia in Spain and Greece, where new cold-spots emerged, the UK, where a few hot-spots disappeared, some regions of Poland, where a few cold-spots disappeared, and Germany, where some new hot-spots appeared.

The spatial autocorrelation for patent applications to the EPO by priority year per million of active population is high, with Moran's $I=0.6$, in 2009 and $I=0.4$ in 2012. From the maps in Figure 3, one can observe clusters of regions with a high number of patent applications surrounded by regions also with a high number of patent applications (high-high cluster, hot-spots) in Finland, Southern Sweden, Germany, France (Lorraine, Alsace, and Burgundy), Belgium (Namur, Hainaut, Flemish Brabant, Antwerp, Limburg, Liège), the Netherlands (Gelderland, South Holland, North 
Brabant, and Limburg), Southern Denmark, Piemonte and Veneto in Italy, and Austria. Cold-spots are located mainly in Portugal and southern Spain, as well as in the Eastern part of the EU, which corresponds with the low numbers of patent applications submitted to the EPO from the CEE regions (Figure 2).

The spatial autocorrelation of employment in technology and knowledge-intensive sectors per economically active population is high, with Moran's $I=0.5$, in 2009 and $I=0.7$ in 2012. In contrast to the earlier indicators, the difference between 2009 and 2012 is noticeable. From the maps in Figure 4, we can observe clusters of regions with high employment surrounded by regions with similarly high employment (high-high) in Namur, Hainaut, Flemish Brabant, Antwerp, Limburg, Liège in Belgium, Eastern Netherlands and North Brabant in the Netherlands. The Northern part of Italy, South West Scotland, North Yorkshire, Tees Valley, and Durham in the UK were in high-high clusters only in 2009. On the other hand, one can observe an additional hot-spot in Romania, and some new hot-spots in Germany, Austria and Benelux. At the same time, we have disappearing cold-spots in Latvia, Estonia and Germany, and even a change from cold- to hot-spot in Thüringen (Germany) over time. Overall, by 2012, the number of hot-spots had increased from 36 to 52, and the number of cold-spots had remained stable; however, it had concentrated mainly in the Iberian Peninsula and Greece.

The spatial autocorrelation of GDP per active population is very high (Moran's $I=0.86$, in 2009 and $I=0.85$ in 2012) with a very similar spatial pattern for both years. From the maps in Figure 4, we can observe hot-spots mainly in Southern Sweden, Scotland, Midlands and the South East of the UK, Northern Italy, Austria, some regions in Germany, Belgium, and the Netherlands. Regions with a low GDP surrounded by regions with a similar level of GDP (low-low) clusters in the Eastern part of the EU. The low-GDP cluster dominates almost the whole CEE region for the whole analysed period 2009-2012, with the notable exception of Estonia.

Overall, the values of GDP, R\&D expenditures, and patent applications to the EPO at the regional level for CEE states are significantly lower than in the rest of the EU. This results in the widespread and significant cold-spots. Hot-spots are more typical for Western and Northern Europe; however, they appear in much smaller clusters. Only in the case of human capital do the Central and Eastern regions not exhibit any clear spatial patterns (except for a hot-spot in Romania in 2012).

The spatial clustering of individual indicators of innovativeness aligns with most RIS conclusions. Moreover, we do observe the spillover effect from Innovation Leaders to Followers.

For R\&D expenditures and patents, we see that South and East Middle Sweden, as well as Stockholm, are indeed Innovation Leaders and the spillover effect can be seen for Småland and the islands. Similarly, in Finland, spillover occurs from Innovation Leaders (Lapland and Helsinki-Uusimaa) to eastern regions, which are Innovation Followers. In the United Kingdom, Innovation Followers like Gloucestershire, Wilt- 
shire, and the Bristol/Bath area mainly benefit from Innovation Leaders: Berkshire, Buckinghamshire, Oxfordshire, Surrey, and East and West Sussex.

In the case of employment in technology and knowledge-intensive sectors, the spatial clustering analysis only partially coincides with RIS innovators classification. The only spilling-over from Innovation Leaders can be seen in Germany, the Netherlands, and Austria. Additionally, human capital is spilling-over from Moderate Innovators in northern Italy.

In our analysis, it is noteworthy that we do not observe any significant impact of Moderate Innovators on neighbouring regions. This is especially visible in the eastern part of the EU.

Figures 5 and 6 present results from the bivariate LISA analysis for the years 2009 and 2012 for all three innovation factors with a regional GDP.

The spatial association between the regional GDP and the total intramural R\&D expenditures in neighbouring regions is high, with Moran's $I=0.7$. From the map, we can observe clusters of regions with a high GDP surrounded by regions with high R\&D expenditures in Finland, Sweden, Germany, the UK, France, the Netherlands, Belgium, Denmark, and Austria. On the other hand, we also have clusters of regions with a low GDP border as well as low R\&D expenditures in the Eastern part of the EU.

Additionally, the spatial association between regional GDP and patent applications to the EPO in bordering regions is high, with Moran's $I=0.69$ in 2009, and $I=0.54$ in 2012. Moreover, local clusters of regions with a high GDP surrounded by regions with a high number of patent applications are visible in regions of Finland, Sweden, Germany, France, the Netherlands, Belgium, Italy, Austria, and the UK. We also have clusters of regions with low GDP adjacent to regions with a low number of patent applications in Greece, Bulgaria, Romania, Poland, Lithuania, Hungary, and additionally Portugal and Spain in 2012.

From Figure 6, it is clear that the global spatial autocorrelation between regional GDP and employment in professional sectors in neighbouring regions is low, with Moran's $I=0.2$. However, one can observe local clusters of regions with a high GDP surrounded by regions with high employment in R\&D in Germany, the Netherlands, Belgium, and Austria. Additionally, there are also clusters of regions with a low GDP bordering low R\&D employment in Portugal and Spain, and in 2012, in Greece and Malopolskie in Poland.

The bivariate analysis confirmed that for CEE regions, low GDP corresponds with low R\&D expenditures and a low number of EPO applications. On the other hand, hot-spots are observed in Western and Northern Europe. Combining the results from the bi- and univariate analysis, it becomes apparent that the EU is divided in terms of innovation. Higher values and high-high clusters appear in the West and the North, while cold-spots and lower values are observed in the Central and Eastern parts, as well the Iberian Peninsula (Figures 2-6)

Recognising the spatial heterogeneity of both the innovation potential and the regional development, we turn to econometric tools to identify any general patterns con- 
necting the GDP level with the indicators of innovation. In the central part of our analysis, to investigate whether the influence of innovation factors in neighbouring regions stimulate economic performance within the region, we performed a spatial Durbin panel model with random and fixed effects $\left(\varphi_{\text {group }(i)}+\varepsilon_{i t}\right)$. To this end, we consider the following specification

$$
\begin{aligned}
G D P_{i t} & =\rho \mathbf{W} G D P_{i t}+\gamma_{1} \mathbf{W} H_{i t}+\gamma_{2} \mathbf{W E P O} O_{i t}+\gamma_{3} \mathbf{W} R \& D \exp _{i t}+ \\
& +\beta_{1} H_{i t}+\beta_{2} E P O_{i t}+\beta_{3} R \& \operatorname{Dexp}_{i t}+\varphi_{\text {group }(i)}+\varepsilon_{i t},
\end{aligned}
$$

where $G D P_{i t}$ represents GDP in the $i$-th region and year $t$ (PPS; constant prices of 2000), $H_{i t}$ - employment in technology and knowledge-intensive sectors per economically active population in the $i$-th region and year $t, E P O_{i t}$ - patent applications to the EPO by priority year per million of active population in the $i$-th region and year $t, R \& \operatorname{Dexp}_{i t}$ - total intramural R\&D expenditure (GERD) (PPS; constant prices of 2000) per economically active population, $\mathbf{W} G D P_{i t}$ indicates the mean of GDP in neighbouring (in the sense of $3 \mathrm{nn}$ weight matrix) regions in year $t$. The variables $\mathbf{W} H_{i t}, \mathbf{W E P O} O_{i t}, \mathbf{W} R \& \operatorname{Dexp}_{i t}$ are defined analogously.

The preliminary results from ML procedures indicated that the level of human capital, as well as patent applications within the given region, does not have a significant or direct impact on economic performance. Their spatial counterparts, however, do.

The final model takes the following form

$$
\begin{gathered}
G D P_{i t}=\rho \mathbf{W G D} P_{i t}+\gamma_{1} \mathbf{W} H_{i t}+\gamma_{2} \mathbf{W E P O} O_{i t}+\gamma_{3} \mathbf{W R} \& D \exp _{i t}+ \\
+\beta_{3} R \& D \exp _{i t}+\varphi_{\text {country }(i)}+\varepsilon_{i t} .
\end{gathered}
$$

Parameter $\varphi_{\text {country }(i)}$ represents spatial effects common for each country (country-specific fixed effect), where $1 \leq$ country $(i) \leq 27,1 \leq i \leq 261$, as the sample consists of 261 regions for 27 countries, and therefore we introduce 27 spatial-fixed effects into the model. In our study, we considered both country-specific and regional fixed effect specifications. However, we found that incorporating the country-specific fixed effects considerably improved the goodness of fit of the model. At the same time, further extending the usual regional fixed effect specification provided virtually no improvement. This implies that employing the country-specific effects made it possible to control the country-specific socio-economic factors, without reducing the number of degrees of freedom too much.

Table 2 presents the estimation results. All coefficients associated with the explanatory variables of the model appear significant at the $5 \%$ confidence level, which suggests that the chosen set of innovation factors significantly explain economic performance in the EU regions. Most importantly, the significance of the spatial coefficient and the spatial lags of the explanatory variables confirms the assumed complex structure 
of the interregional interactions of innovation factors. Furthermore, the value of goodness of fit (0.94) suggests a good adjustment of the model to the empirical data.

Table 2. Spatial Durbin panel model with country-fixed effects

\begin{tabular}{|l|c|c|c|c|}
\hline \multicolumn{1}{|c|}{ Variable } & Estimates & Var & t-value & p-value \\
\hline Rho & 0.146 & 0.036 & 4.071 & $<0.00001$ \\
\hline W H & 0.817 & 0.166 & 4.918 & $<0.00001$ \\
\hline W EPO & 0.021 & 0.009 & 2.263 & 0.023657 \\
\hline W R\&D exp. & -0.039 & 0.015 & 2.604 & 0.009203 \\
\hline R\&D exp. & 0.193 & 0.007 & 26.258 & $<0.00001$ \\
\hline $\mathrm{R}^{2}$ _pseudo with FE & 0.94 & & & \\
\hline $\mathrm{N}$ & 261 & & & \\
\hline $\mathrm{T}$ & 4 & & & \\
\hline
\end{tabular}

Source: own study based on research results done in Matlab.

From the outcomes, we conclude that the inclusion of spatially-weighted human capital in the set of innovation determinants of economic performance proved to be valid. Essentially, employment in technology and knowledge-intensive sectors in nearby regions have a positive impact on regional income. Also, the empirical outcomes show that patent applications to the EPO in neighbouring locations statistically have a significant effect on the economic performance within the region. Therefore, we conclude that regions benefit economically from their locational spillovers in terms of social capital, as suggested by the spatial patterns described by the uni- and bivariate analysis, and confirming the complementary effect of the above innovation factors.

In general, a high level of innovation factors in surrounding locations stimulate economic performance within the region. Interestingly, this does not apply to the expenditures on research and development, however, where we do not see substitution or complementarity between internal R\&D and external technology acquisition.

It should be noted that in the results of the bivariate LISA analysis, strong and positive correlations between GDP and WR\&D have been found. However, the econometric model, in which the decomposition of R\&D expenditures has been applied, revealed that the actual impact on economic performance from nearby regions is negative, though highly significant. This means that the more substantial the expenditures in neighbouring regions, the more impoverished the region, ceteris paribus. So, our results suggest no regional complementarities for R\&D investments. At the same time, a positive and significant coefficient associated with expenditures on in-house research indicates that the more substantial the $\mathrm{R} \& \mathrm{D}$ expenditures within the region, the more prosperous the region. From that, one can conclude that our model reveals a regional competition effect of the $\mathrm{R} \& \mathrm{D}$ expenditures, favouring in-house over outsourced research. This could be caused by the issue of limited resources, where possible, higher funding in one region comes at the expense of other regions, as a result, inhibiting their economic development. 


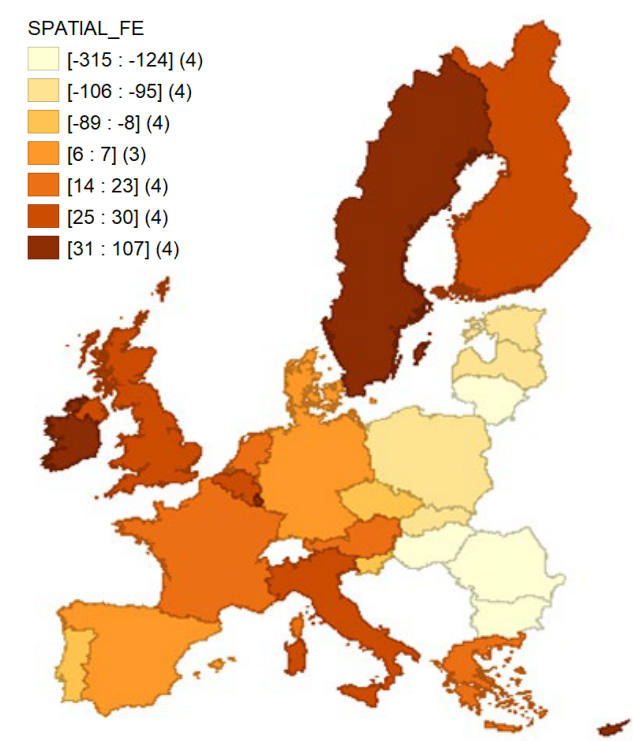

Figure 7. Country fixed effects for regional economic performance for innovation determinants in the EU Source: own study based on research results done in GeoDa.

The final specification of the econometric model confirmed that country-specific effects surpass the individual regional effect and the common constant value for all locations. This means that while in each region the GDP is influenced by its innovativeness as well as the innovativeness of bordering regions, all regions within a single country have a mutual (common) time-constant baseline or starting-point level of regional development. This common factor reveals the contribution of innovation factors in wealth creation. It can be observed that these effects are the lowest in the Balkans, the Baltic States, and Central Europe. Hence, the CEE regions are hindered by their country-specific factors.

\section{Conclusions}

For the analysis of individual regions, we conclude that in the EU, innovation factors appear in a polarised structure with agglomerations in Western and Northern EU versus Eastern and Central EU and the Iberian Peninsula. A similar spatial pattern is also reflected in the RIS report for Innovation Leaders and Strong Innovators versus Moderate and Modest Innovators.

In the case of the Iberian Peninsula, one can observe extremely low employment in science and technology, which has been decreasing over time. This is probably caused by the largest share of the population with the lowest level of education in the EU (Educational attainment statistics). This, together with a very low level of expenditures on research and development, corresponds with the declining development in Spain and Portugal. 
For the Central and Eastern EU, this study recognised a few notable disadvantageous patterns. Firstly, almost all NUTS 2 CEE regions have a low level of regional development. Secondly, they also have low levels of innovativeness, which (as proven by the Durbin model) stimulates global production. Thirdly, country-specific effects identified by the Durbin model hinder the development of NUTS 2 regions due to the relatively low values for the CEE states. Finally, as indicated by the theory and the results of the Durbin model, the regional development of each region is influenced by the situation of its neighbours. Unfortunately, for most analysed variables (studied separately and jointly with GDP), low-low clusters constitute a major share of CEE regions. Therefore, for these regions, spatial interactions can be seen as an obstacle rather than an aid.

This disturbing trend may have severe consequences for the economy in this part of the EU. It should also be noted that while Poland, together with some neighbouring states, like Lithuania, the Czech Republic, and Slovakia, are considered less developed countries in the EU, and rather moderate to modest innovators, their expenditures for research and development and patent applications have been increasing over time. This is also reflected in the high incline of GDP in this part of the EU. This may suggest that the awareness of innovativeness and its influence on regional development has risen in the region. Lastly, the performance of regional innovation appears to be relatively stable throughout the period of analysis.

In this paper, we have aimed to trace knowledge-based innovation factors that determine regional economic performance. Our results validate the assumed complex structure of the interregional interactions of innovation factors. We established that the complementary effect occurs for social capital, namely human capital and patent applications, with strong spillover effects. In the case of research and development expenditures, however, our analysis revealed both regional clustering of similarly high or low R\&D expenses in large parts of Europe, as well as a regional competition effect, which indicates the preference for internal research programs over acquiring external technology. This result of the spatial panel model challenges the cooperation paradigm in the innovation process. Moreover, the spatial analysis indicates that regional innovativeness and regional development are strongly determined by the region's location and "neighbourhood". This constitutes an unfair but unalterable disadvantage to Eastern and Central Europe.

In the analysis, we specified and estimated country fixed effects which represent spatial effects common for each country. They appear to be significant and highly diverse, therefore, essential from the viewpoint of the analysed innovation-determined economic performance process. This factor might be associated with some socio-economic, legal, administrative, or cultural aspects, like the education system or a willingness to take risk, and it reveals the contribution of innovation factors to wealth creation.

Our research reveals that there are spatial patterns in innovation factors, and therefore, innovation is not merely confined to its administrative borders, despite the pres- 
ence of country-specific factors. What is more, there is considerable diversity in the performances of regional innovation indicators. Treating the RIS 2019 as a benchmark for the future analysis, it can be expected that the gap between the Central and Eastern Europe and the Western and Northern parts will not disappear, but may strengthen the polarisation of the EU. Future analysis on an extended timeframe panel would make it possible to trace long-term patterns and their stability over time.

\section{References}

Anselin, L. (1998), Spatial Econometrics: Methods and Models, Kluwer, Dordrecht.

Anselin, L., Le Gallo, J., Jayet, H. (2008), Spatial panel econometrics, [in:] L. Mátyás, P. Sevestre (eds.) The econometrics of panel data, fundamentals and recent developments in theory and practice, $3^{\text {rd }}$ ed., Kluwer, Dordrecht. https://doi.org/10.1007 1978-3-540-75892-1_19

Anselin, L., Varga, A., Acs, Z. (1997), Local Geographic Spillovers between University Research and High Technology Innovations, "Journal of Urban Economics", 42 (3), pp. 422-448. https://doi.org/10.1006/juec.1997.2032

Bilbao-Osorio, B., Rodríguez-Pose, A. (2004), From R\&D to Innovation and Economic Growth in the EU, "Growth and Change", 35 (4), pp. 434-455. https://doi.org/10.11 11/j.1468-2257.2004.00256.x

Boschma, R. (2005), Proximity and innovation - a critical assessment, "Regional Studies", 39 (1), pp. 61-74. https://doi.org/10.1080/0034340052000320887

Brouwer, E., Kleinknecht, A. (1999), Innovative output, and a firm's propensity to patent. An exploration of CIS micro data, "Research Policy", 28 (6), pp. 615-624. https:// doi.org/10.1016/S0048-7333(99)00003-7

Cabrer-Borrás, B., Serran-Domingo, G. (2007), Innovation and R\&D spillover effects in Spanish regions: A spatial approach, "Research Policy", 36, pp. 1357-1371. https:// doi.org/10.1016/j.respol.2007.04.012

Caragliu, A., Nijkamp, P. (2012), The impact of regional absorptive capacity on spatial knowledge spillovers: the Cohen and Levinthal model revisited, "Applied Economics”, 44, pp. 1363-1374. https://doi.org/10.1080/00036846.2010.539549

Cliff, A.D., Ord, J.K. (1981), Spatial processes: models and applications, Taylor \& Francis, London.

Corrado, C., Haskel J., Jona-Lasinio, C. (2017), Knowledge Spillovers, ICT and Productivity Growth, "Oxford Bulletin of Economics and Statistics", 79 (4), pp. 592-618. https://doi.org/10.1111/obes.12171

Corrado, C., Hulten, Ch., Sichel, D. (2009), Intangible capital and U.S. economic growth, “The Review of Income and Wealth", 55 (3), pp. 661-685. https://doi.org/10.1111/j.14 75-4991.2009.00343.x

Crescenzi, R., Rodrígue-Pose, A., Storper, M. (2007), The territorial dynamics of innovation: a Europe - United States comparative analysis, "Journal of Economic Geography”, 7 (6), pp. 673-709. https://doi.org/10.1093/jeg/lbm030

Dominicis, L. de, Florax, R.J.G.M., Groot, H.L.F. de (2013), Regional clusters of innovative activity in Europe: are social capital and geographical proximity key determi- 
nants?, “Applied Economics”, 45 (17), pp. 2325-2335. https://doi.org/10.1080/0003 6846.2012.663474

Educational attainment statistics. http://ec.europa.eu/eurostat/statistics-explained/in dex.php/Educational_attainment_statistics (accessed: 23.02.2020).

Elhorst, J.P. (2014), Spatial Panel Models, [in:] M. Fischer, P. Nijkamp (eds.) Handbook of Regional Science, Berlin, Springer. https://doi.org/10.1007/978-3-642-23430-9_86

Elhorst, J.P., Gross M., Tereanu E. (2018), Spillovers in space and time: where spatial econometrics and Global VAR models meet, European, Central Bank, Frankfurt, Working Paper Series, No. 2134.

European Innovation Scoreboard 2016. https://op.europa.eu/en/publication-detail /-/publication/693eaaba-de16-11e6-ad7c-01aa75ed71a1/language-en/format-PDF /source-31233711 (accessed: 23.02.2020).

Eurostat Regional Database. https:/ec.europa.eu/eurostat/web/regions/data/database (accessed: 23.02.2020).

Frascati Manual (2002). https://www.oecd-ilibrary.org/science-and-technology/frasca ti-manual-2002_9789264199040-en (accessed: 23.02.2020).

Global Innovation Index 2016 report. http://www.wipo.int/edocs/pubdocs/en/wipo _pub_gii_2016.pdf (accessed: 23.02.2020).

Global Innovation Index 2017 report. https://www.globalinnovationindex.org/userfiles /file/reportpdf/gii-full-report-2017.pdf (accessed: 23.02.2020).

Global Innovation Index 2018 report. https://www.globalinnovationindex.org/userfiles /file/reportpdf/gii_2018-report-new.pdf (accessed: 23.02.2020).

Global Innovation Index 2019 report. https://www.globalinnovationindex.org/userfiles /file/reportpdf/GII2019-keyfinding-E-Web3.pdf (accessed: 23.02.2020).

Gonçalves, E., Almaida, E.S. (2009), Innovation and Spatial Knowledge Spillovers: Evidence from Brazilian Patent Data, "Regional Studies", 43 (4), pp. 513-528. https:// doi.org/10.1080/00343400701874131

Granovetter, M. (2005), The impact of social structure on economic outcomes, "Journal of Economic Perspectives”, 19 (1), pp. 33-50. https://doi.org/10.1257/08953300 53147958

Griliches, Z. (1979), Issues in assessing the contribution of research and development to productivity growth, "Bell Journal of Economics", 10 (1), pp. 92-116. https://doi .org/10.2307/3003321

Halleck, V.S., Elhorst J.P. (2016), A regional unemployment model simultaneously accounting for serial dynamics, spatial dependence and common factors, "Regional Science and Urban Economics”, 60, pp. 85-95. https://doi.org/10.1016/j.regsciurbe co.2016.07.002

Jaffe, A.B. (1989), Real effects of academic research, "American Economic Review", 79 (5), pp. 957-970.

Kelejian, H.H., Prucha, I.R. (1998), A Generalised Spatial Two-Stage Least Squares Procedure for Estimating a Spatial Autoregressive Model with Autoregressive Disturbances, "The Journal of Real Estate Finance and Economics", 17 (1), pp. 99-121.

Kelejian, H.H., Prucha, I.R. (2010), Specification and estimation of spatial autoregressive models with autoregressive and heteroskedastic disturbances, "Journal of Econometrics”, 157 (1), pp. 53-67. https://doi.org/10.1016/j.jeconom.2009.10.025 
LeSage, J., Pace, R.K. (2009), Introduction to Spatial Econometrics, Taylor \& Francis Group, New York. https://doi.org/10.1201/9781420064254

Moran, P.A.P. (1948), The Interpretation of Statistical Maps, "Journal of the Royal Statistical Society”, Series B (Methodological), 10 (2), pp. 243-251. https://doi.org/10 $.1111 / \mathrm{j} .2517-6161.1948 . t b 00012 . x$

Olejnik, J., Olejnik, A. (2020), QML estimation with non-summable weight matrices, "Journal of Geographical Systems", 22, pp. 469-495. https://doi.org/10.1007/s10109 -020-00326-2

Ord, K. (1975), Estimation Methods for Models of Spatial Interaction, "Journal of the American Statistical Association”, 70, pp. 120-126. https://doi.org/10.1080/016214 59.1975.10480272

Regional Innovation Scoreboard 2016 report. https://op.europa.eu/en/publication-deta il/-/publication/693eaaba-de16-11e6-ad7c-01aa75ed71a1/language-en/format-PDF /source-31233711 (accessed: 23.02.2020).

Regional Innovation Scoreboard 2017 report. https://op.europa.eu/en/publication-deta il/-/publication/ce38bc9d-5562-11e7-a5ca-01aa75ed71a1/language-en/format-PDF /source-99532255 (accessed: 23.02.2020).

Regional Innovation Scoreboard 2019 report. https://ec.europa.eu/growth/sites/growth /files/ris2019.pdf (accessed: 23.02.2020)

Shi, W., Lee, L.F. (2017), Spatial dynamic panel data model with interactive fixed effects, "Journal of Econometrics", 197, pp. 323-347. https://doi.org/10.1016/j.jecon om.2016.12.001

\section{Streszczenie}

\section{Określenie przestrzennych wzorców determinant innowacji w regionalnych wynikach gospodarczych}

Niniejszy artykuł analizuje rolę czynników innowacyjności w rozwoju regionalnym 261 regionów UE w latach 2009-2012. Analiza przestrzenna wskazała, że regionalna innowacyjność, a dalej rozwój regionalny, zależą nie tylko od położenia geograficznego regionu, ale i jego sąsiadów. Pociąga to za sobą szczególnie poważne konsekwencje dla Europy Środkowo-Wschodniej. Za pomocą przestrzennego modelu panelowego Durbina ze stałymi efektami grupowymi (dla krajów), oceniliśmy wpływ czynników innowacji i ich przestrzennych odpowiedników na regionalne wyniki ekonomiczne. Pokazał on, że regiony czerpią korzyści ekonomiczne ze swoich efektów lokalizacyjnych pod względem kapitału społecznego, jednak w przypadku wydatków na badania i rozwój ujawniono efekt konkurencji między regionami.

Słowa kluczowe: innowacjność regionów, wzorce innowacji, przestrzenne rozprzestrzenianie, czynniki wspólne, przestrzenny ekonometryczny model panelowy 